\title{
Effect of heat treatment on bio-corrosion rate of steel structure (API 5L) in marine evironment
}

\author{
Herman Pratikno ${ }^{1, *}$, Harmin Sulistiyaning Titah ${ }^{2}$, and Bima Ero Dwi Syahputra ${ }^{1}$ \\ ${ }^{1}$ Institut Teknologi Sepuluh Nopember, Department of Ocean Engineering, Faculty of Marine Technology, Indonesia \\ ${ }^{2}$ Institut Teknologi Sepuluh Nopember, Department of Environmental Engineering, Faculty of Civil, Environmental and Geo \\ Engineering, Surabaya, Indonesia
}

\begin{abstract}
One of the cause of corrosion is the attachment of bacteria or commonly called as bio-corrosion or Microbial Influenced Corrosion (MIC). This aim of the research was to determine effect of heat treatment process on the bio-corrosion rate of API 5L steel. The treatments were namely, without heat treatment as a control, and with the heat treatment (austempering process). The austenizing process was conducted before the austempering process. All specimens without and with the heat treatment were be used on bio-corrosion test. The bio-corrosion testing was conducted with immersion corrosion test method with artificial seawater salinity of 35\%. Three of species bacteria were be used, Escherichia coli, Pseudomonas fluorescens, and Thiobacillus ferrooxidans. The result showed the corrosion rate on API 5L steel without bacteria was 2.7558 mpy, but it reached $3.4273,3.6062$ and 3.7699 mpy after addition with $E$. coli, P. fluorescens, and T. ferrooxidans, respectively. It was indicating that bacteria can accelerate the corrosion rate. The highest bio-corrosion rate due to $T$. ferrooxidans without heat treatment process was 3.7699 mpy. Meanwhile, the bio-corrosion rate due to T. ferrooxidans with austempering process was 3.5046 mpy. It was indicating that heat treatment can decrease the bio-corrosion rate.
\end{abstract}

\section{Introduction}

Corrosion is a material damage caused by the influence of the surrounding environment [1]. Corrosion can also be interpreted as a natural event that occurs in the material and is the process of the return of the material to its original state when the material is found and processed from the natural [2]. The corrosion rate is influenced by several factors including: water, gas content and dissolved solids, temperature, material selection, $\mathrm{pH}$, reducing bacteria or Reducing Bacteria Sulfate [3]. One of the cause of corrosion is the attachment of bacteria or commonly called as biocorrosion or Microbial Influenced Corrosion (MIC). One of effort to produce good material and have a good corrosion resistance materials is by heat treatment. Heat treatment is an operation or combination of operations involving heating at a specific rate, soaking at a temperature for a period of time and cooling at some specified rate. The purpose is to obtain a desired microstructure to achieve certain predetermined properties (physical, mechanical, magnetic or electrical) $[4,5]$.

The aim of this research was to determine the effect of austenizing and heat treatment (austempering process), on the bio-corrosion rate of API 5L steel.

\section{Materials and Methods}

\subsection{Preparation of Speciment}

Materials were cut in dimensions of $20 \times 20 \times 3 \mathrm{~mm}$ based on American Society of Mechanical Engineers (ASME).

\subsection{Austenizing and Heat Treatment (Austempering Process)}

The specimens were heated to above the critical temperature to change the steel structure to austenite. API 5L include as low carbon steel or hypoeutectoid, so that the material was heated at $845^{\circ} \mathrm{C}$. The specimen was heated to $845^{\circ} \mathrm{C}$ and then it held holding time for 15 minutes. This process was a austenizing. After that, it was cooled in salt balt with temperature of $300^{\circ} \mathrm{C}$ for 60 minutes to reach stage 1 where the micro structure was bainite [6]. It was a austempering process.

\subsection{Preparation of Bacteria}

The preparation of bacteria was conducted based on our previous study [7]. Three of bacteria were used in this research, i.e. Escherichia coli, Pseudomonas fluorescens, and Thiobacillus ferrooxidans. The pure culture of each bacteria was be inoculated onto nutrient agar (NA)

\footnotetext{
* Corresponding author: hermankelautan@gmail.com
} 
media using streak plate tehnique based on Harley and Prescott [8]. The age of bacteria for bio-corrosion test was $18-24 \mathrm{~h}$. After that, one coloni of bacteria was tranferred to nurient borth (NB) and keep in shaker incubator at $150 \mathrm{rpm}$ and room temperature, $33^{\circ} \mathrm{C}$. The time for shaking process was determination based on the log phase of each species of bacteria. The suspension of bacteria was ready to be used in bio-corrosion test.

\subsection{Preparation of Solution Test}

In this study, chemical solution as a substitute for sea water with salinity $35 \%$ was used based on formula of manufacture of artificial seawater, ASTM D1 141- 9024 [9].

\subsection{Bio-corrosion Test Process}

The process of bio-corrosion testing was conducted using immersion method. In this immersion method, the specimen was immersed in the test solution. The detail of bio-corrosion test steps was described in Pratikno and Titah [10]. Amount of 5\% (v/v) of single bacteria was added in corrosion test solution. All specimens without and with the heat treatment were be used on biocorrosion test.

\subsection{Calculation of Weight Loss Method}

The corrosion rate and bio-corrosion rate in millimeter per year (mm/year) were calculated from weight of material loss during test, with this formula based ASTM G1-72 [11].

Corrosion rate $(m p y)=\frac{K \cdot W}{D \cdot A \cdot T}$

$\mathrm{W}=$ Weight loss $(\mathrm{g})$

$\mathrm{K}=$ Konstanta $\left(\mathrm{mpy}=3,45 \times 10^{6}\right)$

$\mathrm{D}=$ Density $\left(\mathrm{g} / \mathrm{cm}^{3}\right)$

$\mathrm{A}=$ Surface Area $\left(\mathrm{cm}^{2}\right)$

$\mathrm{T}=$ Exposure Time (Hours)

\subsection{Microstructure Observation}

Etching was caaried out in order to obtain an observable surface with an optical microscope using Nital solution [12]. Nital is a mixture of $98 \mathrm{ml}$ of alcohol and $2 \mathrm{ml}$ of nitric acid. After the etching solution was ready, the surface of the speciment test was immersed in the etching solution for about 3-5 seconds. And then, it rinsed with running water and cleaned with a tissue and dried using a hair-dryer.

Metallographic test is the observation of microstructure on specimens test. The observation was conducted under optical microscope Axiocam Carl Zeiss Vission 4.4 (Germany) with magnification of $100 \mathrm{X}$ and $500 \mathrm{X}$. All specimens, before and after treatments, were analysed for metallographic test.

\section{Results and Discussion}

\subsection{Corrosion Rate}

Fig. 1 depicted the corrosion rate of API 5L steel without bacteria and after added with single bacteria. The result showed the corrosion rate on API 5L steel without bacteria was $2.7558 \mathrm{mpy}$, but it reached $3.4273,3.6062$ and 3.7699 mpy after addition with $E$. coli, $P$. fluorescens, and T. ferrooxidans, respectively. It was indicating that bacteria can accelerate the corrosion rate. This condition was similar with our previous study, the bio-corrosion rate on steel structire of ASTM A53 and A106 increased by two-fold compared with the condition without bacteria addition [13]. Based on our previous study, T. Ferrooxidans caused the highest bio-corrosion rate $(1.3212 \mathrm{~mm} /$ year) in salinity of $33 \%$ compared with bio-corrosion rate by $E$. coli and $P$. fluorescens on ASTM A53. Meanwhile, the maximum bio-corrosion rate by $T$. ferrooxidans on ASTM A106 was 1.253 $\mathrm{mm} /$ year.

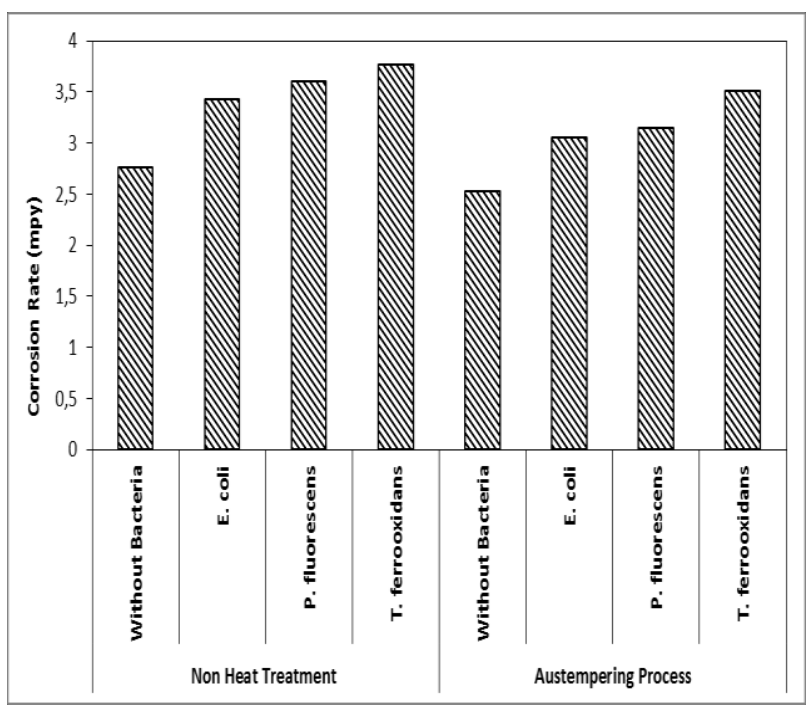

Fig. 1. Corrosion Rate on API 5L steel.

The highest bio-corrosion rate due to $T$. ferrooxidans on API 5L steel without heat treatment process was 3.7699 mpy. Meanwhile, the bio-corrosion rate due to $T$. ferrooxidans on API 5L steel with austempering process was $3.5046 \mathrm{mpy}$. This condition also occured on biocorrosion rate due to presence of $E$. coli and $P$. fluorescens. It was indicating that heat treatment can decrease the bio-corrosion rate. However, heat treatment also can decrease the corrosion rate without bacteria.

\subsection{Microstructure}

API 5L steel is a type of steel pipe with a carbon content of $0.28 \%$ [14]. The carbon content of API $5 \mathrm{~L}$ is included in the category of low carbon steel (low carbon steel) or commonly called hypoeutectoid. Steel material without heat treatment after observation of its micron structure consists of ferrite and pearlite. Fig. 2 (a),(b) showed the metallographic test results without heat treatment. The 
composition of visible microstructure were ferrite and pearlite with a balanced composition.

Meanwhile, this balanced of ferrite and pearlite changed due to heat treatment process. Fig. 2 (c),(d) depicted microstructure observation after austenizing and austempering process. The material was transformed

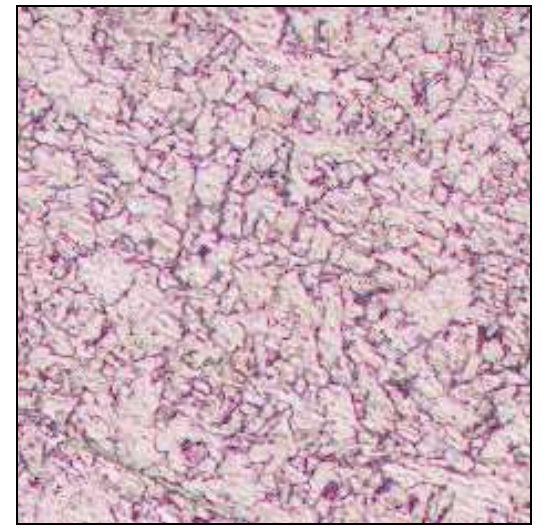

(a) $100 \mathrm{X}$ - before heat treatment

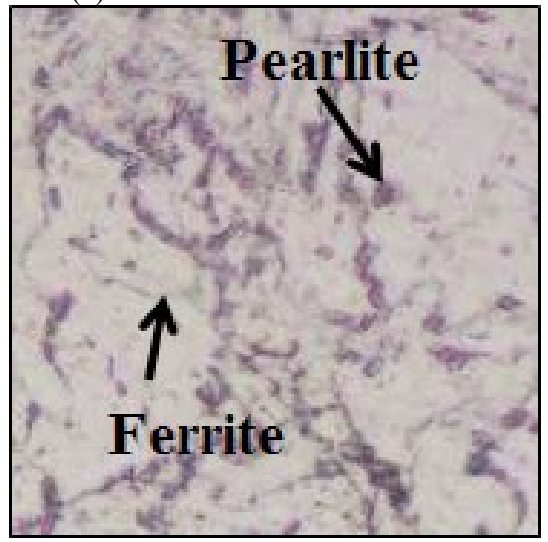

(b) $500 \mathrm{X}$ - before heat treatment

Fig. 2. (a), (b) Initial microstructure of API 5L specimen, (c), austempering process.

Fig. 3 (a,b) showed the microstructure on API 5L speciment as a control speciment or without bacteria addition after corrosion test at salinty of 35\%. Corrosion rate in seawater is approximately at 0.1 to $0.2 \mathrm{~mm} /$ year with a good access to oxygen. Corrosion aggressiveness of seawater not only is a function of water resistivity and salinity, but it also is influenced by other mutually supplementary factors such as temperature, $\mathrm{pH}$ reaction, oxygenation, water flow, dissolved gas content and pollutants [15]. According to Paul [16], chloride ion increases the corrosion rate. Furthermore, dissolved salts, especially ion $\mathrm{Cl}^{-}$, are unfavourable for passive metals and may cause local passive layer failures initiating pitting corrosion [17].

Based on microstructure observation (Fig. 3 c, d), the surface of API 5L with presence of bacteria revealed a isothermally and transformed into a bainite that has properties hard but tenacious. Structure of bainite was black and elongated with magnification of 500X in Fig. (d). This condition can improve the hardness of surface speciment. And then, it can decrease the bio-corrosion rate.

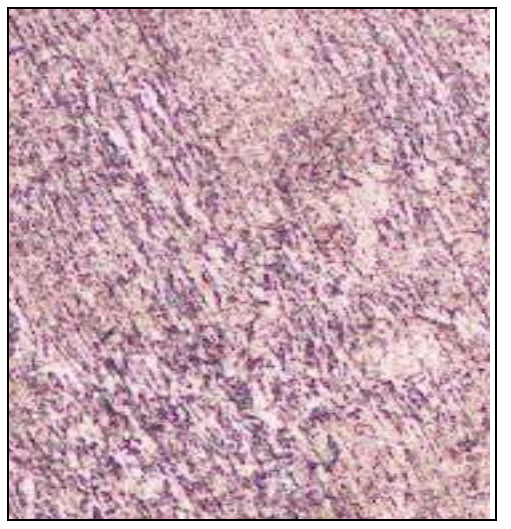

(c) $100 \mathrm{X}$ - after austenizing and austempering process

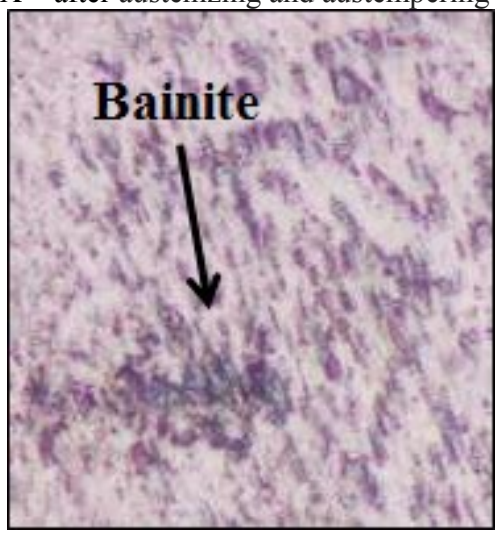

(d) 500X - after austenizing and austempering process

c), (d) Microstructure of API 5L specimen after austenizing. and

large quantity of corrosion products and more corrosion pits and uniform corrosion were evident. Pitting corrosion and uniform corrosion on API $5 \mathrm{~L}$ in presence all species of bacteria. It indicated that the ability of single species of Escherichia coli, Pseudomonas fluorescens, and Thiobacillus ferrooxidans to cause corrosion and form defects, cracking, pits and holes result from corrosion process which had covered the surface of API 5L. Thomas et al. [18] suggested that the presence of a biofilm may act as a diffusional barrier to the corrosive substances. Bacteria secrete EPS to envelope and to anchor them to the substrate there by altering the local surface chemistry which can stimulate further growth and settlement of macro organisms [19]. 


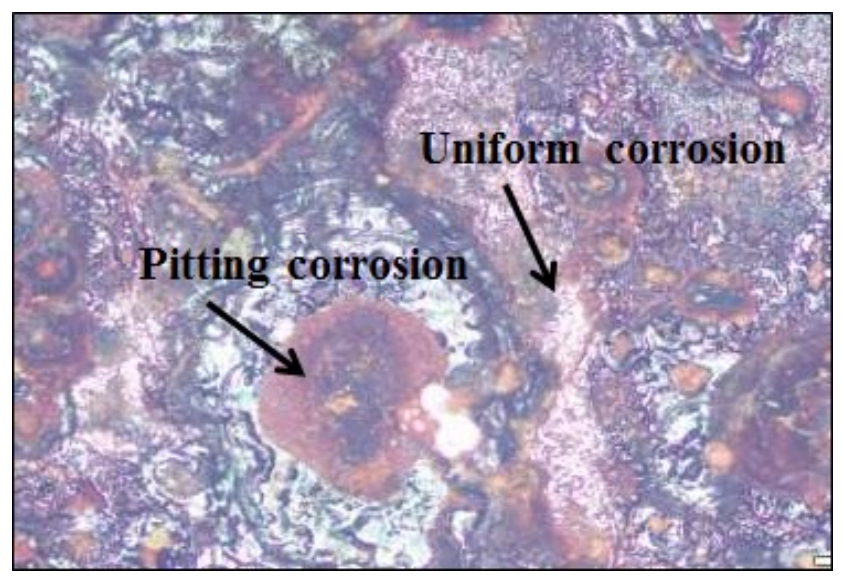

(a) without bacteria

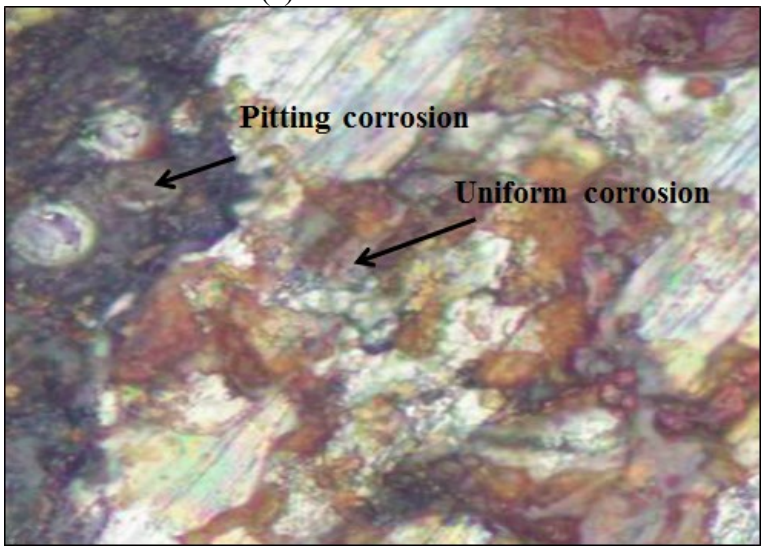

(b) with bacteria of $E$. coli

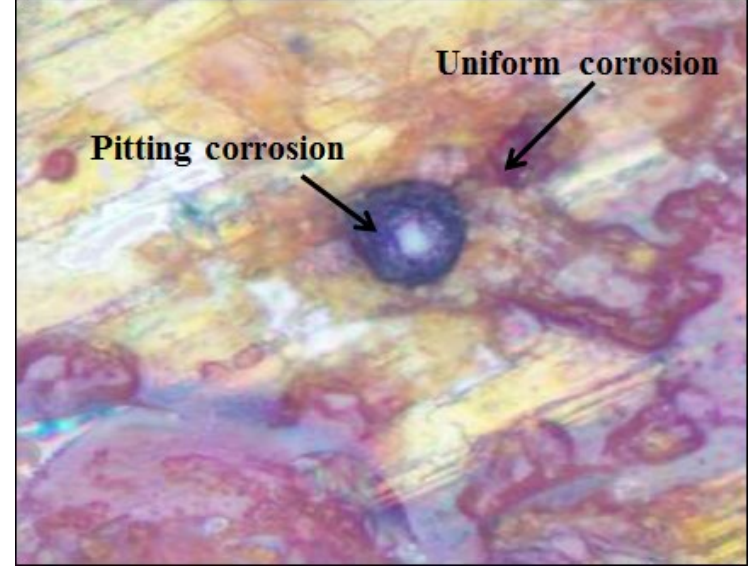

(c) with bacteria of P. fluorescens

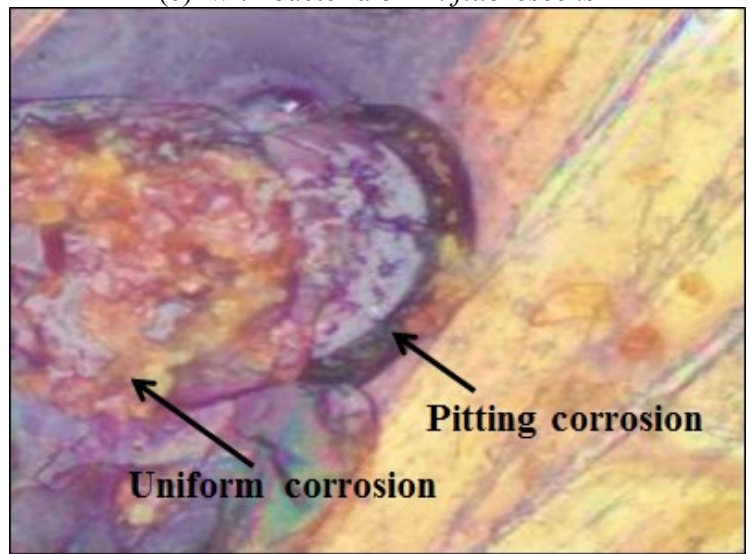

(d) with bacteria of $T$. ferrooxidans

Fig. 3. Microstructure after bio-corrosion test in magnifcation of 500X., (a) without bacteria, (b) with bacteria of $E$. coli, (c) with bacteria of $P$. fluorescens, (d) with bacteria of $T$. Ferrooxidans.

\section{Conclusion}

Based on the results, three bacteria, Escherichia coli, Pseudomonas fluorescens, and Thiobacillus ferrooxidans can accelerate the corrosion rate on API 5L steel. The highest bio-corrosion rate was caused by $T$. ferrooxidan. The austenizing and heat treatment (austempering process) can decrease the bio-corrosion rate.

\section{References}

1. J. Chamberlain, K.R. Trethewey. Korosi untuk mahasiswa dan Rekayasawan. (Jakarta: PT Gramedia Pustaka Utama, 1991).

2. Supriyanto. Pengaruh Konsentrasi Larutan $\mathrm{NaCl}$ 2\% dan 3,5\% Terhadap Laju Korosi Pada Baja Karbon Rendah (Surakarta: Universitas Muhammadiyah Surakarta 2007)

3. ASM Handbook Vol.13, Corrosion: Fundamental, Testing, and Protection (USA: ASM International 2003)

4. C.S. Barrett, Structure of Metals (Horney Press. 2007)

5. S.C. Jirapure, A. Borade. Int. Journal of Eng. Res. and Gen. Sci. 2(5) (2014)
6. K-E.Thelning, Steel and Heat Treatment second edition (Replika Press, Pvt Ltd, EOU.Delhi 110 040, India, 1984)

7. P. Herman, H.S. Titah. IPTEK, The Journal for Technology and Science, 28(2)55-58 (2017)

8. J.P. Harley, L.M. Prescott. Laboratory exercises in microbiology. Fifth Edition. (McGraw-Hill Companies, Texas, 2002)

9. ASTM D1 141-90. Chemical composition of artificial seawater (1990)

10. H. Pratikno, H.S. Titah. Int. Journal of ChemTech Res. 9(12) 600-609 (2016)

11. ASTM G31-72, Standart for Laboratory Immersion Corrosion Testing of Metals. (ASTM Internasioanl. United State, 2014)

12. Anonymous. The Science Behind Materials Preparation, (BUEHLER ${ }$ SUM-MET, USA. 2007)

13. P. Herman, H.S. Titah. Asian Journal of Appl. Sci. 9,120-125 (2016)

14. API. Spesification $5 L$ Forty-third edition. Spesification for line pipe. Washington : API Published Service (2004)

15. L.S. McNeill, M. Edwards. Environ. Monitor and Assess 77(3)229-242 (2002)

16. S.Paul. ISRN Metallurgy 1-6 (2012)

17. S. Ylasaari, et al. Res and Appl. 247 83-92 (1997) 
18. C.J. Thomas, R.G.J. Edyvean, R. Brook. Biofouling 1 65-77 (1988)

19. V. Sarala, M. Radhakrishnan, R. Balagurunathan. Int. Journal of ChemTech Res. 3(3) 1225-1231 (2011) 